As before we used the life table method of analysis, ${ }^{3}$ whereby the number of patients in remission at the start of each month is expressed as a percentage of those having treatment in that month. This allows for the analysis of data from patients entering and leaving the study at different times.

The 43 patients under investigation were followed up for from one to 26 months (mean (SEM) $4 \cdot 8(0 \cdot 7)$ months). During this time 15 relapsed, after a mean of $3.6(0.6)$ months, and five withdrew. The remaining $23(53 \%)$ had not relapsed after a mean of $6.3(1 \cdot 2)$ months. The 75 control patients were followed up for four to 16 months (mean 5.4 (0.4) months). The $23(31 \%)$ who did not relapse were followed up for a mean of $8.8(1.0)$ months. The figure shows the chances of patients in these two groups remaining in remission. At 16 months the chance of being in remission was $42 \%$ for patients in this study compared with $13 \%$ for the control patients; the difference between the curves was significant $(p<0.03)$. Our analysis finished at 16 months, though one patient in this study continued for 26 months without relapsing.

\section{Discussion}

The results show that relapse of chronic plaque psoriasis treated with dithranol can be postponed or prevented by giving psoralens and ultraviolet $A$ once a week. In our study of patients given psoralens and ultraviolet $\mathbf{A}$ as treatment and then as prophylaxis we found that there was little difference in the incidence of relapse between treatment given weekly and once every three weeks, ${ }^{2}$ so it is possible that if the frequency of treatment was reduced the dose of ultraviolet A given after treatment with dithranol could be reduced below the $10 \cdot 6$ $\mathrm{J} / \mathrm{cm}^{2} / \mathrm{month}$ that we used.

The $42 \%$ chance our patients had of remaining in remission at 16 months is not as good as the $80 \%$ chance that we found in patients given psoralens and ultraviolet $\mathrm{A}$ as both treatment and prophylaxis. ${ }^{2}$ A possible explanation is that in the previous study the starting prophylactic dose of ultraviolet $\mathrm{A}$ was the same as the dose at the end of the clearance regimen, which was roughly three times that given initially to the present patients, whose dose was according to skin type.

We are grateful to the Newcastle health authority research fund for a grant and to Dr Vella Briffa for further details of some of the patients in a previous joint study.

\section{References}

${ }^{1}$ Rogers S, Marks J, Shuster S, Briffa DV, Warin AP, Greaves MW. Comparison of photochemotherapy with dithranol in the treatment of chronic plaque psoriasis. Lancet 1979; i:455-8.

${ }^{2}$ Briffa DV, Greaves MW, Warin A, Rogers S, Marks J, Shuster S. Relapse rate and long-term management of plaque psoriasis after treatment with photochemotherapy and dithranol. Br Med F. 1981 ;282: 937-40.

${ }^{3}$ Colton T. Longitudinal studies and the use of the life table. Statistics in medicine. Boston: Little, Brown and Co, 1974:237-50.

(Accepted 7 November 1983)

\title{
Diabetic hypertriglyceridaemia and related 5' flanking polymorphism of the human insulin gene
}

\author{
N I JOWETT, L G WILLIAMS, G A HITMAN, D J GALTON
}

\begin{abstract}
A polymorphic DNA sequence was studied on the $5^{\prime}$ flanking region of the human insulin gene in relation to diabetic lipaemia. The genotype frequencies in a control population $(n=52)$ were homozygous $L$ $6 \%$, heterozygous $54 \%$, and homozygous S $40 \%$. Corresponding genotype frequencies in a hypertriglyceridaemic group $(n=74)$ were $18 \%, 66 \%$, and $16 \%\left(p<0.01 ; \chi^{2}\right.$ test $)$. When the hypertriglyceridaemic patients were divided on the basis of glucose tolerance the corresponding genotype frequencies in the diabetic subgroup $(n=23)$ were $39 \%$, $52 \%$, and $9 \%$ compared with $0 \%, 74 \%$, and $26 \%$ in the non-diabetics $(\mathbf{n}=34)\left(\mathbf{p}<0.001 ; \chi^{2}\right.$ test).

These findings suggest that the homozygous $L$ genotype may confer susceptibility to diabetic hypertriglyceridaemia.
\end{abstract}

\section{Introduction}

Hypertriglyceridaemia, defined as a fasting serum triglyceride concentration exceeding $2 \mathrm{mmol} / 1(177 \mathrm{mg} / 100 \mathrm{ml})$, is a heterogeneous group of disorders that occurred in more than $10 \%$ of men in a British population. ${ }^{1}$ The aetiology of the common forms of the disorder is poorly understood but is generally considered to include an interaction between genetic and environmental factors. In rare instances the disease may be due to a single gene defect involving the synthesis of either lipoprotein lipase or its peptide activator apoprotein C-II. ${ }^{2}{ }^{3}$ In the common forms of hypertriglyceridaemia it is possible that several gene variants confer susceptibility to the effects of environmental factors such as excess dietary carbohydrate or alcohol. In support of this view we have recently observed a polymorphic DNA locus close to the apoprotein A-1 gene which appears to segregate with patients who have hypertriglyceridaemia. ${ }^{4}$ In view of the probable polygenic nature of this disorder we are studying other gene or gene associated variants which may associate with the disease.

Insulin is one of the major hormones that influences the circulating concentrations of plasma triglyceride. It is required for maintaining the activity of lipoprotein lipase in tissues, which is central in the clearance of plasma triglyceride ${ }^{5}$; and in insulin resistant or deficient states hypertriglyceridaemia commonly results. ${ }^{6}$ There is also a close relation between hyperglycaemia and hypertriglyceridaemia when the secretion or action of insulin is impaired.

The human insulin gene is located on the short arm of chromosome $11 .{ }^{7}$ At one end of the gene $\left(5^{\prime}\right)$ is a highly variable
Department of Medicine, St Bartholomew's Hospital, London EC1A 7BE

N I JOWETT, MB, MRCP, honorary senior registrar

L G WILLIAMS, PHD, senior biochemist

G A HITMAN, MB, MRCP, honorary senior registrar

D J GALTON, MD, FRCP, consultant physician

Correspondence to: Dr D J Galton. 
locus due to insertions of differing lengths of DNA. ${ }^{8}$ This polymorphic locus may be detected as changes in the pattern of DNA fragments generated after digestion of the human genome with specific restriction endonucleases and separated by agarose gel electrophoresis. ${ }^{9}$

Increased frequency of a large DNA insertional class has been reported in association with non-insulin dependent diabetes, ${ }^{10} 11$ although other investigators have not confirmed this. ${ }^{812}$ The discrepancy may in part be due to the heterogeneity of diabetes, and possibly the association exists within diabetic subtypes which have been variably represented in the previous studies. We have therefore looked for possible associations between features of this polymorphic locus and diabetes related disorders. We report our findings in diabetic hypertriglyceridaemia.

\section{Patients and methods}

We studied 74 patients with hypertriglyceridaemia serially selected from the lipid clinic at this hospital. Table I gives their clinical details. The group was defined by a mean pretreatment serum triglyceride concentration greater than $2 \mathrm{mmol} / 1(177 \mathrm{mg} / 100 \mathrm{ml})$ in three separate fasting venous blood samples, and complete lipid analysis showed that the group comprised WHO classes IIb and IV/V in equal numbers. A control group of 52 subjects was selected from other outpatient clinics and a health screening clinic. All had normal fasting blood lipid and sugar concentrations-glucose $<6 \mathrm{mmol} / 1$ $(108 \mathrm{mg} / 100 \mathrm{ml})$, total cholesterol $<6.5 \mathrm{mmol} / 1(250 \mathrm{mg} / 100 \mathrm{ml})$, triglyceride $<2 \mathrm{mmol} / 1(177 \mathrm{mg} / 100 \mathrm{ml})$. None had a personal or family history of diabetes, hyperlipidaemia, or cardiovascular disease. All groups were white, and the ages of the control group were comparable with those of the patient groups at the onset of their disease. In addition, 22 non-insulin dependent diabetics who were normolipaemic at diagnosis were selected from our diabetic clinic to serve as a second control group (table I). Six of the hypertriglyceridaemic patients were known to have non-insulin dependent diabetes. A further 51 patients were assessed by a standard $75 \mathrm{~g}$ oral glucose tolerance test, performed as recommended by WHO, ${ }^{13}$ and the 57 hypertriglyceridaemic patients were then subdivided into either diabetic or non-diabetic hypertriglyceridaemia, according to WHO criteria. ${ }^{13}$ Two subjects had impaired glucose tolerance and were dropped from the study.

At the time of genotyping, hyperglycaemia was being treated in diabetic patients by diet alone (seven patients), oral hypoglycaemic agents (12 patients), and insulin (four patients), although none of the diabetics were insulin dependent-that is, there was no history of previous diabetic ketoacidosis. Despite adequate hypoglycaemic treatment, hypertriglyceridaemia had persisted requiring further dietary manipulation as well as treatment with hypolipidaemic drugs including clofibrate and nicotinic acid.

\section{DNA ANALYSIS}

DNA was isolated from leucocytes in $10 \mathrm{ml}$ venous blood, essentially by the method of Kunkel et al. ${ }^{14}$ Previously collected anticoagulated blood, stored at $-20^{\circ} \mathrm{C}$, was thawed and diluted with $90 \mathrm{ml}$ lysis buffer (sucrose $0.32 \mathrm{~mol} / 1(110.0 \mathrm{~g} / \mathrm{l}), \mathrm{MgCl}_{2} 5.0 \mathrm{mmol} / 1(47.6 \mathrm{mg}$ ) $100 \mathrm{ml}$ ), $1 \%$ Triton X-100, trometamol (TRIS) $10 \mathrm{mmol} / 1$ (121 mg/ $100 \mathrm{ml}), \mathrm{pH} 7 \cdot 5)$. The nuclear fraction was separated by centrifugation and resuspended in $4.5 \mathrm{ml}$ saline edetic acid $(\mathrm{NaCl} 75 \mathrm{mmol} / \mathrm{l}(438 \mathrm{mg} /$ $100 \mathrm{ml}$ ), edetic acid $24 \mathrm{mmol} / 1(7 \mathrm{mg} / \mathrm{ml}), \mathrm{pH} 8 \cdot 0)$. Sodium dodecyl sulphate and proteinase $\mathrm{K}$ (Sigma Chemicals) were added to final concentrations of $17 \mathrm{mmol} / 1(4.9 \mathrm{mg} / \mathrm{ml})$ and $200 \mu \mathrm{g} / \mathrm{ml}$ respectively and the mixture incubated at $37^{\circ} \mathrm{C}$ for 12 hours. DNA was then extracted with $10 \mathrm{ml}$ trometamol buffered phenol (trometamol 20 $\mathrm{mmol} / \mathrm{l}(242 \mathrm{mg} / 100 \mathrm{ml})$, $\mathrm{pH} 8.0)$ followed by further extraction with $10 \mathrm{ml}$ 24:1 chloroform and isoamyl alcohol. After further centrifugation the DNA was precipitated from the supernatant by adding $0.5 \mathrm{ml} 3 \mathrm{M}$ sodium acetate $(\mathrm{pH} 5.0)$ and $11 \mathrm{ml}$ ethanol at room temperature. The DNA was then redissolved in trometamol: edetic acid buffer $(10 \mathrm{mmol}: 1 \mathrm{mmol} / 1 ; 121 \mathrm{mg}: 29 \mathrm{mg} / 100 \mathrm{ml})$ at $\mathrm{pH} 7 \cdot 5$.

DNA samples were digested with restriction endonuclease $\mathrm{Bgl} 1$ according to the manufacturer's specifications (BRL Ltd) and electrophoresed on $0.85 \%$ agarose gel. Transfer to filters and hybridisation were performed by Southern's blotting technique. ${ }^{15}$ The gene probe used contained the entire sequence for the human insulin gene, labelled with ${ }^{32} \mathrm{P}$ to a specific activity of $>5 \times 10^{6}$ $\mathrm{cpm} / \mu \mathrm{g}$ DNA by "nick" translation. ${ }^{16}$ Hybridisation bands were visualised by autoradiography and fragment sizes (in kilobases; $\mathbf{k b}$ ) estimated from Hind III digested lambda phage markers (BRL Ltd).

\section{STATISTICAL ANALYSIS}

The association of DNA inserts with diabetes or hypertriglyceridaemia, or both, was analysed by a $3 \times 2$ contingency table comparing the presence of one or more insertional alleles with the disease group. A $\chi^{2}$ test of independence was performed. Relative incidence ("risk factor") was calculated by the method of Woolf ${ }^{17}$ as: relative incidence $(x)=\mathrm{WK} / \mathrm{Hk}$, where $\mathrm{W}$ is the number of patients with the test genotype, $\mathrm{H}$ the number of controls with the test genotype, $\mathrm{K}$ the number of controls with the "normal" genotype, and $k$ the number of patients with the normal genotype.

\section{Results}

Two major classes of DNA insertion were identified at the polymorphic locus-large (L: $4 \cdot 6+0 \cdot 6 \mathrm{~kb})$ and small (S: $2 \cdot 8+0.4 \mathrm{~kb})-$ and the 148 unrelated subjects shown in table I genotyped as $L L$, LS, or SS (table II). The figure shows an example of an autoradiograph. In our hypertriglyceridaemic population we found a higher frequency of patients with the homozygous large genotype compared with the non-diabetic, normolipaemic controls $(p<0.01)$. When the two control groups were compared (normolipaemic diabetic versus normolipaemic non-diabetic) no significant difference was found $(p>0 \cdot 3)$. The hypertriglyceridaemic subjects were then divided into those with diabetes and those without diabetes on the basis of the result of the oral glucose tolerance test. When the genotypes of these two groups were compared a large difference in the frequency of the homozygous (LL) genotype was found, both when the subgroups were compared directly $(\mathbf{p}<0.001)$ and when the diabetic hypertriglyceridaemic patients were compared with controls $(p<0.001)$.

TABLE I-Clinical features of study groups

\begin{tabular}{|c|c|c|c|c|c|}
\hline & \multicolumn{2}{|c|}{ Control subjects } & \multicolumn{3}{|c|}{ Hypertriglyceridaemic subjects } \\
\hline & $\begin{array}{l}\text { Non-diabetic, } \\
\text { normolipaemic }\end{array}$ & $\begin{array}{l}\text { Diabetic, } \\
\text { normolipaemic }\end{array}$ & Total & Diabetic & Non-diabetic \\
\hline No of subjects & 52 & 22 & 74 & 23 & 34 \\
\hline $\begin{array}{l}\text { Mean (SD) age in years [range] } \\
\text { Mean (SD) age at diagnosis }\end{array}$ & $50.9(8 \cdot 6)[24-73]$ & $\begin{array}{l}59 \cdot 0(6 \cdot 8)[40-62] \\
50 \cdot 0(6 \cdot 4)\end{array}$ & $\begin{array}{l}53 \cdot 7(8 \cdot 5)[26-71] \\
48 \cdot 6(8 \cdot 6)\end{array}$ & $\begin{array}{l}57 \cdot 9(7 \cdot 1)[46-71] \\
50 \cdot 5(7 \cdot 9)\end{array}$ & $\begin{array}{l}52 \cdot 9(6 \cdot 7)[38-69] \\
48 \cdot 7(7 \cdot 0)\end{array}$ \\
\hline$\%$ Men & 50 & 79 & 83 & 81 & 87 \\
\hline $\begin{array}{l}\text { Mean (SD) fasting pretreatment } \\
\text { [range]: } \\
\text { Cholesterol (mmol/l) } \\
\text { Triglycerides }(\mathrm{mmol} / \mathrm{l}) \\
\text { Plasma glucose }(\mathrm{mmol} / \mathrm{l})\end{array}$ & $\begin{array}{l}5 \cdot 1(1 \cdot 3)[4 \cdot 1-6 \cdot 4] \\
1 \cdot 3(0 \cdot 38)[0 \cdot 8-1 \cdot 6] \\
3 \cdot 8(0 \cdot 59)[2 \cdot 7-4 \cdot 2]\end{array}$ & $\begin{array}{c}6 \cdot 2(1 \cdot 5)[4 \cdot 9-6 \cdot 5] \\
1 \cdot 5(0 \cdot 41)[1 \cdot 1-1 \cdot 8] \\
18 \cdot 7(8 \cdot 3)[9 \cdot 1-38 \cdot 8]\end{array}$ & $\begin{array}{l}7 \cdot 9(2 \cdot 1)[4 \cdot 8-14 \cdot 6] \\
5 \cdot 7(4 \cdot 7)[2 \cdot 1-19 \cdot 5] \\
8 \cdot 9(4 \cdot 1)[3 \cdot 2-31 \cdot 0]\end{array}$ & $\begin{array}{r}8 \cdot 3(2 \cdot 2)[5 \cdot 3-14 \cdot 5] \\
6 \cdot 0(5 \cdot 6)[2 \cdot 1-19 \cdot 5] \\
14 \cdot 1(5 \cdot 9)[8 \cdot 9-31 \cdot 0]\end{array}$ & $\begin{array}{l}7 \cdot 9(2 \cdot 3)[4 \cdot 8-14 \cdot 6] \\
6 \cdot 2(5 \cdot 0)[2 \cdot 2-19 \cdot 3] \\
4 \cdot 1(0 \cdot 74)[3 \cdot 2-5 \cdot 7]\end{array}$ \\
\hline $\begin{array}{l}\text { Weight*: } \\
\% \text { Normal } \\
\% \text { Overweight } \\
\% \text { Obese }\end{array}$ & $\begin{array}{l}65 \\
23 \\
12\end{array}$ & $\begin{array}{l}51 \\
33 \\
16\end{array}$ & $\begin{array}{l}50 \\
29 \\
21\end{array}$ & $\begin{array}{l}52 \\
30 \\
18\end{array}$ & $\begin{array}{l}45 \\
32 \\
23\end{array}$ \\
\hline
\end{tabular}

*From the recommendations of the Fogarty Centre conference on obesity $1973^{21}$ and based on the original Metropolitan Life Insurance tables 1959.

Conversion: SI to traditional units-Cholesterol: $1 \mathrm{mmol} / 1 \approx 38 \cdot 6 \mathrm{mg} / 100 \mathrm{ml}$. Triglycerides: $1 \mathrm{mmol} / 1 \approx 88 \cdot 5 \mathrm{mg} / 100 \mathrm{ml}$. Glucose: $1 \mathrm{mmol} / 1 \approx 18 \mathrm{mg} / 100 \mathrm{ml}$. 
TABLE II-Insulin gene polymorphism genotypes and allele frequencies in subjects with or without diabetes and hypertriglyceridaemia

\begin{tabular}{|c|c|c|c|c|c|c|}
\hline \multirow[t]{2}{*}{ Study group } & \multirow[t]{2}{*}{ No } & \multicolumn{3}{|c|}{ Genotype } & \multicolumn{2}{|c|}{$\begin{array}{c}\text { Allele } \\
\text { frequency }\end{array}$} \\
\hline & & LL & LS & ss & $\mathbf{L}$ & $\mathbf{S}$ \\
\hline \multicolumn{7}{|l|}{$\begin{array}{l}\text { Controls: } \\
\text { Normoglycaemic, } \\
\text { normolipaemic }\end{array}$} \\
\hline $\begin{array}{l}\text { subjects } \\
\text { Normolipaemic diabetics }\end{array}$ & $\begin{array}{l}52 \\
22\end{array}$ & $3(6 \%)$ & $28(54 \%)$ & $21(40 \%)^{\mathrm{a}}$ & 0.33 & 0.67 \\
\hline $\begin{array}{l}\text { Normolpaemic diabetics } \\
\text { Hypertriglyceridaemic }\end{array}$ & & $3(14 \%)$ & $13(59 \%)$ & $6(27 \%)^{0}$ & 0.43 & 0.57 \\
\hline $\begin{array}{l}\text { Total } \\
\text { Diabetics } \\
\text { Non diabetics }\end{array}$ & $\begin{array}{l}74 \\
23 \\
34\end{array}$ & $\begin{array}{r}13(18 \%) \\
9(39 \%) \\
0(0 \%)\end{array}$ & $\begin{array}{l}49(66 \%) \\
12(52 \%) \\
25(74 \%)\end{array}$ & $\begin{array}{r}12(16 \%)^{c} \\
2(9 \%)^{d} \\
9(26 \%)^{\mathrm{e}}\end{array}$ & $\begin{array}{l}0.51 \\
0.65 \\
0.37\end{array}$ & $\begin{array}{l}0.49 \\
0.35 \\
0.63\end{array}$ \\
\hline
\end{tabular}

$\chi^{2}$ analysis for comparison of genotypes using $3 \times 2$ contingency table with two degrees of freedom: control $v$ b $\chi^{2}=1.985, \mathrm{NS}$; control $v$ c $\chi^{2}=10.92, \mathrm{p}<0.01$;
control $v \mathrm{~d} \chi^{2}=16.32, \mathrm{p}<0.001$; control $v$ e $\chi^{2}=4.39$, NS; $v$ e $\chi^{2}=16.54, \mathrm{p}<0.001$.

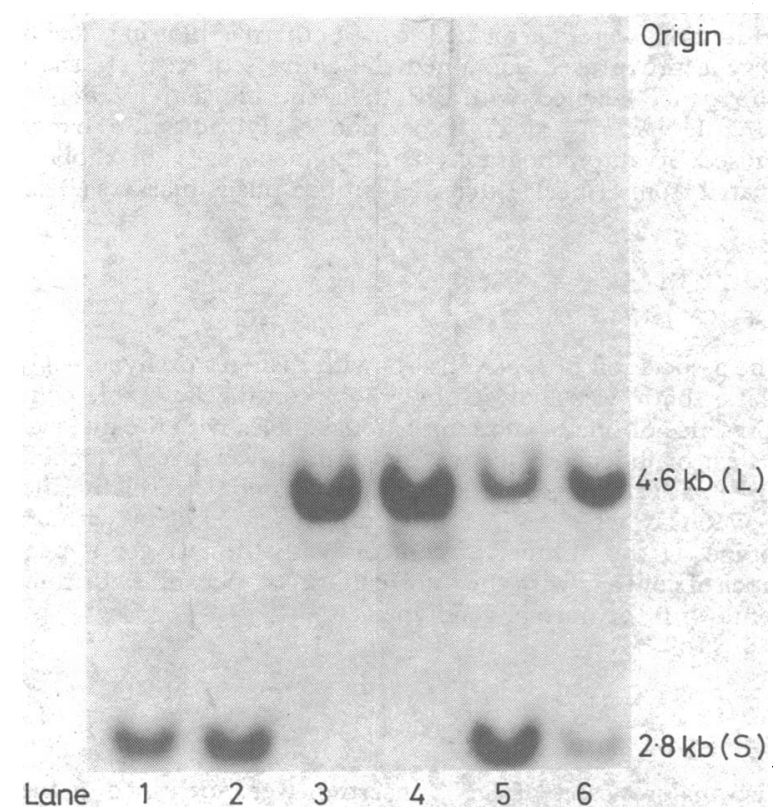

Autoradiograph of DNA (from six hypertriglyceridaemic patients) digested with restriction endonuclease Bgl 1 and hybridised with 32P labelled human insulin gene probe.

Genotypes: lanes 1, 2 homozygous small (SS); lanes 3, 4 homozygous large (LL); lanes 5, 6 heterozygous (LS).

There was no difference in genotype distribution between the WHO lipaemic groups IIb and IV/V.

\section{Discussion}

The highly polymorphic region at the $5^{\prime}$ end of the human insulin gene is produced by a variable number of repeated DNA sequences being inserted at this site. ${ }^{18}$ Although this locus exists in many different lengths, depending on how many DNA sequences are inserted, the distribution in white people is essentially bimodal, having either fewer than 90 or more than 130 repeats - the remaining sizes being comparatively rare. At present there is no generally agreed classification, but most investigators distinguish either large $(L)$ or small $(S)$ insertions, referred to by others as upper or lower ${ }^{10}$ and as classes 1 and $3 .^{\circ}$

We have found a disease association of the homozygous large (LL) genotype with diabetic hypertriglyceridaemia. Calculation of the relative incidence of the homozygous large genotype shows that there is an increased risk factor of 10.5 for the development of diabetes and hypertriglyceridaemia in the general population if they possess this genotype (LL). The equivalent risk factor for an established non-insulin dependent diabetic with this genotype (LL) developing hypertriglyceridaemia is $4 \cdot 0$.
Non-insulin dependent diabetes is associated with the homozygous large genotype, ${ }^{111}$ and, since about half of these diabetics may have plasma lipid abnormalities at presentation, ${ }^{19}$ we used as a second control group non-insulin dependent diabetics who were normolipaemic at diagnosis. When that group was compared with our normal controls (normoglycaemic, normolipaemic) there was no statistical difference $(p>0.3)$, which suggests that the increased prevalence of the large insert noted by some workers in non-insulin dependent diabetes may have been due to a preponderance of diabetics with hypertriglyceridaemia in their study groups. Although our group of normolipaemic diabetics was comparatively small $(n=22)$, the prevalence of the homozygous large genotype was $14 \%$ compared with only $6 \%$ in the non-diabetic, normolipaemic controls. Analysis of more normolipaemic diabetics will disclose whether this genotype associates equally with both non-insulin dependent diabetes and diabetic hypertriglyceridaemia or is found only in increased frequency in this latter subgroup of diabetes. It may be that the homozygous large genotype in a patient with non-insulin dependent diabetes confers susceptibility to coexistent hypertriglyceridaemia.

Observations by Owerbach et al suggested that there may be an increased frequency of the large allele in patients with atherosclerosis and that it may be a genetic marker for the disorder. ${ }^{20}$ Lipid analyses were not reported, and possibly their clinical groups contained a high proportion of patients with hypertriglyceridaemia. As both diabetes and hypertriglyceridaemia are implicated in the genesis of atheroma, the combination of these two conditions would, as we have shown, be associated with an increased prevalence of the large insert. The findings of Owerbach et al, however, must be considered to be preliminary as a relatively small number of patients were genotyped and atheroma was estimated only on the basis of a patient questionnaire. Any further work in this direction must clearly take into account serum lipid analysis, and the degree of atheroma should be defined angiographically.

The role of the polymorphic locus in the aetiology of diabetes and hypertriglyceridaemia is unknown. It is unlikely to be transcribed into a protein as the peptide would be of variable size, and every third amino acid would be glycine or proline, depending on which strand was transcribed. Although the locus is close enough to the insulin gene to affect transcription, there is no evidence in vivo or in vitro that it does so. It is clearly not required for a gene specific function, as no corresponding region is found flanking the rat insulin gene. ${ }^{18}$ Possibly the polymorphism is in linkage disequilibrium for other genes on the short arm of chromosome 11 which confer a predisposition to hypertriglyceridaemia and glucose intolerance. Further work is in progress to identify such "disease susceptibility" genes by linkage analysis in diabetic and hyperlipidaemic family pedigrees.

This work received financial support from the Medical Research Council (to DJG), British Diabetic Association (to GAH), and the Joint Research Board of St Bartholomew's Hospital (to NIJ and LGW). We acknowledge Professor R Williamson and Dr S Humphries, of St Mary's Hospital Medical College, for use of their facilities, and thank especially Dr G Bell for the gift of the gene probe.

\section{References}

1 Lewis B, Chait A, Wootton JDP, et al. Frequency of risk factors for ischaemic heart disease in a healthy British population. Lancet 1974 ; : 141-6.

2 Galton DJ, Stocks J, Dodson PM. Lipoproteins: their role in enzyme regulation. Clinical Biochemistry Review 1982;3:377-405.

${ }^{3}$ Breckenridge WC, Little JA, Steiner G, Chow A, Poapst M. Hypertriglyceridemia associated with deficiency of apolipoprotein C-II. $N$ Engl f Med 1978;298:1265-72.

4 Rees A, Shoulders CC, Stocks J, Galton DJ, Baralle FE. DNA polymorphism adjacent to the human apoprotein A-1 gene: relation to hypertriglyceridaemia. Lancet 1983 ; :444-6.

5 Pykalisto OJ, Smith PH, Brunzell JD. Determinants of human adipose tissue lipoprotein lipase. $\mathcal{F}$ Clin Invest 1975;56:1108-17. 
${ }^{6}$ Taylor KG, Galton DJ, Holdsworth G. Insulin-independent diabetes: a defect in the activity of lipoprotein lipase in adipose tissue. Diabetologia $1979 ; 16: 313-7$.

${ }^{7}$ Owerbach D, Bell GI, Rutter WJ, Shows TB. The insulin gene is located on chromsome 11 in humans. Nature 1980;286:82-4.

${ }^{8}$ Bell GI, Karam JH, Rutter WJ. Polymorphic DNA region adjacent to the $5^{\prime}$ end of the human insulin gene. Proc Natl Acad Sci USA 1981; 78:5758-66.

${ }^{9}$ Bell GI, Karam JH. The polymorphic locus flanking the human insulin gene: is there an association with diabetes mellitus? In: Banbury report 14: applications of recombinant DNA in human disease. Cold Spring Harbor: Cold Spring Harbor Press (in press).

10 Owerbach D, Nerup J. Restriction fragment length polymorphism of the insulin gene in diabetes mellitus. Diabetes $1982 ; 31: 275-7$.

1 Rotwein PS, Chirgwin J, Province $M$, et al. Polymorphism in the 5 '-flanking region of the human insulin gene: a genetic marker for non-insulin dependent diabetes. $N$ Engl f Med 1983;308:65-71.

12 Ullrich A, Dull TJ, Gray A, Philips JA, Peter S. Variation in the sequence and modification state of the human insulin gene flanking regions. Nucleic Acids Res 1982;10:2225-40.

${ }^{13}$ WHO Expert Committee on Diabetes Mellitus. Second report. WHO Tech Rep Ser 1980; No 646

${ }^{14}$ Kunkel LM, Smith KD, Boyer SH, et al. Analysis of human Y chromo- some specific reiterated DNA in chromosome variants. Proc Natl Acad Sci USA 1977;74:1245-9.

15 Southern EM. Detection of specific sequences among DNA fragments separated by gel electrophoresis. F Mol Biol 1975;98:503-17.

${ }^{16}$ Rigby PWJ, Dieckmann M, Rhodes C, Berg P. Labelling deoxyribonucleic acid to high specific activity in vitro by nick translation with DNA polymerase 1 . F Mol Biol 1977;113:237-51.

17 Woolf $B$. On estimating the relation between blood group and disease. Ann Hum Genet 1955;19:251-3.

${ }^{18}$ Bell GI, Selby MJ, Rutter WJ. The highly polymorphic region near the human insulin gene is composed of simple tandemly repeating sequences. Nature 1982;295:31-5.

19 Reckless JPD, Betteridge DJ, Wu P, Payne B, Galton DJ. High-density and low-density lipoproteins and prevalence of vascular disease in diabetes mellitus. $\mathrm{Br}$ Med $\mathcal{F}$ 1978; :883-6.

${ }^{20}$ Owerbach D, Billesbolle P, Schroll M, Johansen K, Poulsen S, Nerup J. Possible association between DNA sequences flanking the insulin gene and atherosclerosis. Lancet 1982;ii:1291-3.

${ }^{21}$ Bray. Obesity in perspective. NIH publication 75-708. Fogarty International Center for Advanced Study, 1973.

\title{
Pigmentation and skin reaction to sun as risk factors for cutaneous melanoma: Western Canada Melanoma Study
}

\author{
J M ELWOOD, R P GALLAGHER，G B HILL，J J SPINELLI，J C G PEARSON，W THRELFALL
}

\begin{abstract}
Between 1 April 1979 and 31 March 1981, 904 residents of the four western provinces of Canada (population 6.5 million), were diagnosed as suffering from primary cutaneous malignant melanoma. Of 801 patients aged 20-79 years, $665(83 \%)$ were interviewed along with control subjects chosen at random from the general population and matched for age, sex, and province. After exclusion of 70 subjects with lentigo maligna or acral lentiginous melanoma, comparisons of the 595 casecontrol pairs showed that light hair, skin, and eye colour, a history of heavy freckling in adolescence, and a tendency to burn readily and tan poorly in the sun were significant risk factors for melanoma. The strongest primary associations were with blond hair (relative risk $7 \cdot 1$ compared with black hair), light colour of unexposed skin (relative risk $2 \cdot 4$ ), and severe freckling (relative risk $2 \cdot 1)$. These associations were independent of ethnic origin and of recorded amount of exposure to the sun and were somewhat stronger for superficial spreading than for nodular melanoma.
\end{abstract}

This study is the largest and most detailed of an incident series of melanomas to be published to date. The results were consistent with other studies reporting associations between melanoma and poor tanning ability, a tendency to burn easily, and a history of sunburn and showed that light hair colour was the strongest risk factor for the disease.

\section{Introduction}

Malignant melanoma is of concern because of the rapid increases in incidence and mortality rates which have been seen in almost all white populations with available data, including Canada, the United States, Australia, the United Kingdom, and several other European countries. ${ }^{1-5}$ In Canada mortality rates doubled in a recent 15 year period, making melanoma one of the most rapidly increasing tumours. ${ }^{1}$ The incidence of melanoma and mortality of the disease increase with decreasing latitude in Australia, in the North American continent, and within England and Wales, although in Europe the geographical pattern is more complex because of ethnic and social factors. ${ }^{4-9}$ Patients with melanoma reportedly tend to have lighter complexion, hair, and eye colour, ${ }^{10-13}$ although the early studies that documented these features were limited in that the groups of subjects with whom patients with melanoma were compared were either undefined or included patients with other skin complaints and non-melanomatous skin cancer. While two more recent casecontrol studies showed such differences in pigmentation, ${ }^{14} 15$ two others showed no major differences. ${ }^{16} 17$

Our report is the first from the Western Canada Melanoma Study; 904 incident cases of primary cutaneous melanoma were ascertained, representing all new diagnoses for a continuous geographical area with a population of 6.5 million. Each subject interviewed was matched with a control subject chosen from the general population, and a detailed interview was carried out in the subject's home. This report is based on 595 subjects aged 20-79 years with superficial spreading or nodular melanoma and their matched controls and examines the characteristics of pigmentation and reaction of the skin to sun. 